\title{
Habitat modelling of crabeater seals (Lobodon carcinophaga) in the Weddell Sea using the multivariate approach Maxent
}

\author{
Dominik A. Nachtsheim ${ }^{1,2} \cdot$ Kerstin Jerosch ${ }^{1} \cdot$ Wilhelm Hagen $^{2} \cdot$ Joachim Plötz $^{1}$ • \\ Horst Bornemann ${ }^{1}$
}

Received: 15 November 2015/Revised: 9 June 2016/Accepted: 25 July 2016/Published online: 6 August 2016

(C) The Author(s) 2016. This article is published with open access at Springerlink.com

\begin{abstract}
The crabeater seal (Lobodon carcinophaga) is the most abundant Antarctic seal and inhabits the circumpolar pack ice zone of the Southern Ocean. Until now, information on important environmental factors affecting its distribution as well as on foraging behaviour is limited. In austral summer 1998, 12 crabeater seals of both sexes and different age classes were equipped with satellitelinked dive recorders at Drescher Inlet $\left(72.85^{\circ} \mathrm{S}, 19.26^{\circ} \mathrm{E}\right)$, eastern Weddell Sea. To identify suitable habitat conditions within the Weddell Sea, a maximum entropy (Maxent) modelling approach was implemented. The model revealed that the eastern and southern Weddell Sea is especially suitable for crabeater seals. Distance to the continental shelf break and sea ice concentration were the two most important parameters in modelling species distribution throughout the study period. Model predictions demonstrated that crabeater seals showed a dynamic response to their seasonally changing environment emphasized by the favoured sea ice conditions. Crabeater seals utilized ice-free waters substantially, which is potentially explained by the comparatively low sea ice cover of the Weddell Sea during summer 1998. Diving
\end{abstract}

Electronic supplementary material The online version of this article (doi:10.1007/s00300-016-2020-0) contains supplementary material, which is available to authorized users.

Dominik A. Nachtsheim

d.nachtsheim@outlook.de

1 Alfred-Wegener-Institut Helmholtz-Zentrum für Polar- und Meeresforschung, Am Handelshafen 12,

27570 Bremerhaven, Germany

2 BreMarE - Bremen Marine Ecology, Marine Zoology, University of Bremen, P.O. Box 330440, 28334 Bremen, Germany behaviour was characterized by short $(>90 \%=0-4 \mathrm{~min})$ and shallow $(>90 \%=0-51 \mathrm{~m})$ dives. This pattern reflects the typical summer and autumn foraging behaviour of crabeater seals. Both the distribution and foraging behaviour corresponded well with the life history of the Antarctic krill (Euphausia superba), the preferred prey of crabeater seals. In general, predicted suitable habitat conditions were congruent with probable habitats of krill, which emphasizes the strong dependence on their primary prey.

Keywords Crabeater seal $\cdot$ Weddell Sea $\cdot$ Habitat modelling $\cdot$ Maxent $\cdot$ Species distribution $\cdot$ Foraging behaviour · Antarctic krill

\section{Introduction}

The crabeater seal (Lobodon carcinophaga) is by far the most abundant Antarctic pinniped species comprising an estimated population size between 5 and 7 million individuals, of which a major portion is found in the Weddell Sea (Erickson and Hanson 1990; Bester and Odendaal 2000; Forcada et al. 2012; Southwell et al. 2012). Reliable abundance estimates are difficult to obtain, since crabeater seals inhabit the hardly accessible Antarctic pack ice zone (Joiris 1991; Bester et al. 2002; Ackley et al. 2003; Southwell et al. 2012). Their life cycle is tightly coupled to the availability of sea ice that they occupy for breeding, mating, moulting and resting (Siniff et al. 1979; Bengtson and Cameron 2004; Southwell 2004). Apart from visual observations using transect methods, which are limited to hauled-out animals only, very few studies provide insights into the distribution and habitat use of crabeater seals. Throughout the year, they tend to be associated with 
medium-to-high sea ice concentrations as revealed by few satellite tracking programmes (Nordøy et al. 1995; Burns et al. 2004; Wall et al. 2007; Ballard et al. 2012). However, during our study period in summer 1998 the sea ice cover of the Weddell Sea was comparatively low, with a deviation of $-250,000 \mathrm{~km}^{2}$ to the mean (Cavalieri and Parkinson 2008; Schwegmann 2012). For crabeater seals, this exceptionally low sea ice extent could have implied a severe reduction of their habitat. Crabeater seals have been reported to avoid open waters if possible (Nordøy et al. 1995; Burns et al. 2004), although in eastern Antarctica these seals spent a significant amount of time in ice-free waters (Wall et al. 2007). Thus, the reaction of crabeater seals to such drastic habitat changes is not clear. This may become increasingly important with regard to the predicted decrease of sea ice cover in the Southern Ocean (Siniff et al. 2008; Forcada et al. 2012).

Despite their name, crabeater seals feed almost exclusively on Antarctic krill (Euphausia superba), which represents about $90 \%$ of their diet (King 1961; Øritsland 1977; Lowry et al. 1988; Hückstädt et al. 2012). During summer months, adult krill is abundant in the surface layer both under sea ice and in open waters (Siegel 2005; Taki et al. 2005; Nicol 2006; Flores et al. 2012). The diving behaviour of crabeater seals typically reflects the vertical distribution of their primary prey, with dives being mostly short and shallow, preferably around midnight under lower light levels, when krill tends to migrate towards the surface (Bengtson and Stewart 1992; Nordøy et al. 1995; Wall et al. 2007). Furthermore, crabeater seals seem to be attracted by the continental shelf break and areas between 2500 and $5000 \mathrm{~m}$ depth off the shelf (Nordøy et al. 1995; Ackley et al. 2003; Southwell et al. 2005; Wall et al. 2007). Antarctic krill is generally abundant both over the continental shelf and in oceanic areas in the Atlantic sector (Atkinson et al. 2008), but aggregates at the continental shelf break during summer, while spawning females are usually found offshore in the open ocean (Siegel 2005; Nicol 2006). Thus, habitat preferences of crabeater seals are generally associated with the distribution of krill. This seems obvious, although it has been hypothesized that the distribution of crabeater seals is influenced more by a suitable physical environment (e.g. sea ice availability) providing sufficient food supply over larger time scales than a direct access to their prey (Friedlaender et al. 2011). Since a simultaneous ocean-wide assessment of the distribution and biomass of the seals' prey would be almost impossible, a model that predicts the seals' presence on the basis of available environmental parameters is of high relevance.

In this study, we investigated the influence of certain environmental variables on the distribution and movements of crabeater seals in the Weddell Sea by applying a presence-only habitat modelling approach called maximum entropy (Maxent). Maxent predicts the presence probability of a certain species in the study area on the basis of known environmental variables by identifying the probability distribution of maximum entropy (Phillips et al. 2006). With this approach, suitable habitats for crabeater seals were detected within the Weddell Sea. Identifying favoured habitat conditions is especially important in the context of a recent initiative led by Germany for creating a large marine protected area in the Weddell Sea (Teschke et al. 2013). Furthermore, we analysed the diving behaviour with regard to their foraging ecology and seasonality, and we evaluated how the crabeater seals dealt with the unusually low sea ice cover in summer 1998.

\section{Materials and methods}

\section{Seal tagging site and animal handling}

The satellite-tagging programme on crabeater seals was part of a joint seal sea ice study within the Ecology of the Antarctic Sea Ice Zone (EASIZ) II research expedition of RV Polarstern into the Weddell Sea in austral summer 1998 (Arntz and Gutt 1998). All seals were tagged at Drescher Inlet $\left(72.85^{\circ} \mathrm{S}, 19.26^{\circ} \mathrm{E}\right)$, a $25-\mathrm{km}$-long funnelshaped crack located in the Riiser-Larsen Ice Shelf at the eastern Weddell Sea coast (Fig. 1).

Fifteen crabeater seals of both sexes and different age classes were equipped with satellite-linked dive recorders

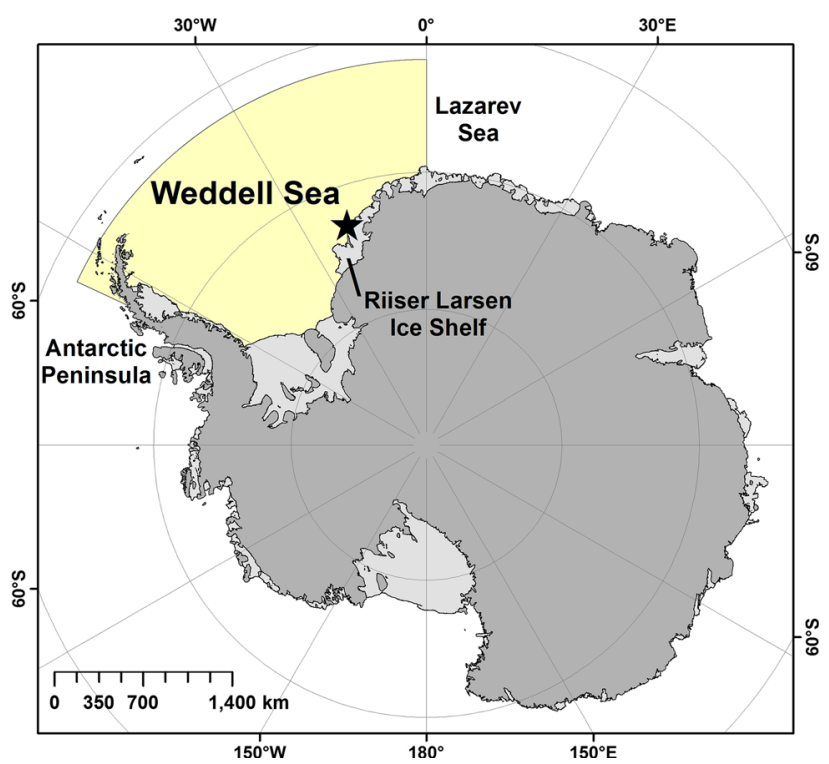

Fig. 1 Location of Drescher Inlet (star) in the eastern Weddell Sea. Antarctica (dark grey) with ice shelves (light grey). The yellow polygon illustrates the study area selected for Maxent modelling analyses 
(SDRs) between 28 January and 6 February 1998 as an integral component of the multinational Antarctic Pack Ice Seals (APIS) programme (Table 1). APIS aimed at a circumpolar assessment of the distribution and abundance of pack ice seals (Southwell et al. 2012). Seals were chosen opportunistically for instrumentation upon their presence during a period of sea ice disintegration onset of the Drescher Inlet's fast ice habitat. The resulting heterogeneous sample of seals can be divided into three age classes (yearlings: $\geq 1$ year, subadults: $2-3$ years, adults: $>3$ years) on the basis of standard body length (Laws et al. 2003). Adults were defined as individuals that have presumably reached the age of sexual maturity (3-5 years in general; Bengtson and Siniff 1981; Bengtson and Laws 1985). Prior to the tagging, the seals were immobilized with a combination of $500 \mathrm{mg}$ xylazine, $400 \mathrm{mg}$ ketamine and 50 I.U. hyaluronidase, known as "Hellabrunner Mischung" (HM). Doses of 2-3 ml HM were supplemented with 2-3 ml ketamine (100 $\left.\mathrm{mg} \mathrm{ml}^{-1}\right)$ and injected with Telinject ${ }^{\circledR}$-blowpipe darts. Maintenance of narcosis was ensured by manual follow-up doses of ketamine, and/or xylazine and/or diazepam on demand. The immobilization procedure is described in detail by Bornemann et al. (1998); see Bornemann and Plötz (2006) for dose rates. While the seals were immobilized, their standard body length was measured with the animal lying on its venter and SDRs were attached to the fur on the animal's back with quick-setting epoxy glue. These were supposed to fall off during the seals' next annual moult. However, timing of the campaign required some individuals to be tagged during moult.

The immobilization of crabeater seals and the deployment of satellite transmitters were approved by the German Federal Environmental Agency (AZ 94003-1/6) and carried out pursuant to the Scientific Committee on Antarctic Research (SCAR) Code of Conduct for Animal Experiments.

\section{Tag settings}

The SDRs (SDR-T6; Wildlife Computers, Redmond, WA, USA) delivered at-sea locations through communication with the Argos System via polar-orbiting satellites (CLS/ Service Argos, Toulouse, France) in tandem with information about the seals' diving behaviour. Dive depth and dive duration were recorded by sorting the maximum depth and duration of each dive into one of 14 user-defined bins on-board the SDR (Table 2). Dive records were accumulated in histogram bins for a period of $6 \mathrm{~h}$ and transmitted to the Argos satellites. The transducer provided dive depths with a resolution of $\pm 3 \mathrm{~m}$. The minimum depth to be considered a dive was set to $6 \mathrm{~m}$ (twice the resolution of the transducer) to separate surfacing and potential offset deviations of the pressure transducer from "true" dives, and thus avoiding superimposing of the first dive bin with "false" dives. Dive depth measurements were restricted by
Table 1 Information about 15 crabeater seals (Lobodon carcinophaga) tagged with satellite-linked dive recorders (SDRs) at Drescher Inlet in 1998. Age class was determined on the basis of standard body length (Laws et al. 2003). Track length was calculated in ArcGIS based on filtered seal locations

\begin{tabular}{|c|c|c|c|c|c|c|c|}
\hline Seal No. & Sex & Age class & $\begin{array}{l}\text { Body } \\
\text { length }(\mathrm{cm})\end{array}$ & $\begin{array}{l}\text { SDR deployment } \\
\text { date }\end{array}$ & $\begin{array}{l}\text { SDR } \\
\text { longevity (d) }\end{array}$ & Last location & $\begin{array}{l}\text { Track } \\
\text { length }(\mathrm{km})\end{array}$ \\
\hline 1 & Male & Adult & 225 & 28/01/1998 & 35 & $71.963^{\circ} \mathrm{S}, 33.167^{\circ} \mathrm{W}$ & 924 \\
\hline 2 & Male & Adult & 223 & 29/01/1998 & 7 & $73.611^{\circ} \mathrm{S}, 38.257^{\circ} \mathrm{W}$ & 201 \\
\hline $3^{\mathrm{a}}$ & Female & Adult & 236 & 29/01/1998 & 0 & $72.877^{\circ} \mathrm{S}, 19.131^{\circ} \mathrm{W}$ & - \\
\hline $4^{\mathrm{a}}$ & Male & Yearling & 182 & 01/02/1998 & 0 & - & - \\
\hline 5 & Male & Yearling & 178 & 01/02/1998 & 17 & $71.926^{\circ} \mathrm{S}, 27.855^{\circ} \mathrm{W}$ & 909 \\
\hline 6 & Male & Yearling & 188 & 01/02/1998 & 117 & $66.874^{\circ} \mathrm{S}, 45.762^{\circ} \mathrm{E}$ & 4554 \\
\hline 7 & Male & Yearling & 189 & 01/02/1998 & 59 & $70.794^{\circ} \mathrm{S}, 32.414^{\circ} \mathrm{W}$ & 1747 \\
\hline 8 & Male & Yearling & 186 & 01/02/1998 & 103 & $65.449^{\circ} \mathrm{S}, 24.551^{\circ} \mathrm{W}$ & 3391 \\
\hline 9 & Female & Subadult & 204 & 02/02/1998 & 73 & $65.698^{\circ} \mathrm{S}, 55.483^{\circ} \mathrm{E}$ & 3796 \\
\hline 10 & Male & Adult & 227 & 03/02/1998 & 60 & $71.705^{\circ} \mathrm{S}, 24.601^{\circ} \mathrm{W}$ & 1380 \\
\hline 11 & Male & Yearling & 193 & 03/02/1998 & 39 & $70.416^{\circ} \mathrm{S}, 37.236^{\circ} \mathrm{W}$ & 979 \\
\hline 12 & Male & Yearling & 184 & 03/02/1998 & 38 & $72.334^{\circ} \mathrm{S}, 44.679^{\circ} \mathrm{W}$ & 1196 \\
\hline $13^{\mathrm{a}}$ & Male & Subadult & 208 & 04/02/1998 & 2 & $72.830^{\circ} \mathrm{S}, 19.844^{\circ} \mathrm{W}$ & - \\
\hline 14 & Female & Adult & - & 04/02/1998 & 96 & $69.205^{\circ} \mathrm{S}, 15.771^{\circ} \mathrm{W}$ & 1504 \\
\hline 15 & Male & Yearling & 188 & 06/02/1998 & 15 & $67.108^{\circ} \mathrm{S}, 14.889^{\circ} \mathrm{W}$ & 786 \\
\hline
\end{tabular}

\footnotetext{
${ }^{\text {a }}$ Since SDRs of seal 3, 4 and 13 transmitted for a maximum of 2 days only, these animals were omitted in further analyses
} 
Table 2 User-defined upper limits of histogram bins for dive parameters. Bin steps for dive depth were chosen heuristically in $10 \mathrm{~m}$ steps for the first $100 \mathrm{~m}$, followed by $50 \mathrm{~m}$ steps up to $250 \mathrm{~m}$.

\begin{tabular}{ll}
\hline Dive parameter & Upper bin limits \\
\hline Dive depth $(\mathrm{m})$ & $9,21,30,42,51,60,72,81,90,102,150,201,252,>252$ \\
Dive duration $(\mathrm{min})$ & $1,2,3,4,5,6,7,8,9,10,11,12,13,>13$
\end{tabular}

the upper limit of the pressure transducer of the individual transmitter varying between 741 and $756 \mathrm{~m}$. In addition to dive depth and dive duration encoded as histograms, the absolute maximum dive depth of a day was post hoc processed and transmitted together with technical information in a status message.

Data handling was done with Microsoft Office Excel 2010 (@) Microsoft Corporation, USA), while all data analyses and generation of related diagrams were conducted in R version 3.1.2 (R Core Team 2014). All Argos locations and dive data as well as the corresponding metadata information are available via the data library PANGAEA (doi:10.1594/PANGAEA.854842).

\section{Filtering of seal tracks}

Crabeater seal tracking data were filtered in two steps. First, we applied a simple filtering algorithm developed by Freitas et al. (2008) in the R environment (R package argosfilter). Highly inaccurate locations were removed as well as those, which exceeded unrealistic swimming speeds of $3.5 \mathrm{~m} \mathrm{~s}^{-1}$ and/or turning angles smaller than $15^{\circ}$ and $25^{\circ}$ between consecutive data points with extensions greater than 2500 and $5000 \mathrm{~m}$, respectively (Freitas et al. 2008).

In a second step, we filtered the pre-filtered Argos satellite telemetry dataset by fitting a joint estimation or hierarchical state-space model (hSSM) using the R package bsam (Jonsen et al. 2013; Jonsen 2016). Two Markov chains of 60,000 samples were run, from which the first 40,000 were disregarded as burn-in. From the remaining 20,000 , only every 20 th sample was retained leading to 1000 samples per chain. These 2000 samples were generated for each seal location and were used to obtain a position estimate as well as the associated uncertainty. We chose a time-step of $6 \mathrm{~h}$ between consecutive locations, which adds up to a constant number of four positions per day and animal. This ensures a consistent representation of each individual within the subsequent Maxent analysis. The hSSM also allows improved inference about hidden behavioural states along the seal tracks, i.e., if an animal was either in a transient or in a resident state at a given location (Jonsen 2016). Filtered seal tracks were then plotted in ArcGIS for Desktop 10.2 (ㄷ ESRI, Inc., USA) for visualization.
Bin limits needed to match with an even multiple of the resolution of the pressure transducer $(3 \mathrm{~m})$

\section{Environmental data}

A set of 13 environmental variables was used to analyse the habitat preferences of crabeater seals: sea ice concentration $(\%)$, sea ice thickness $(\mathrm{m})$, sea ice freezing rate $\left(\mathrm{cm} \mathrm{d}^{-1}\right)$, water surface and bottom temperature $\left({ }^{\circ} \mathrm{C}\right)$, surface and bottom salinity, surface and bottom zonal current velocity $\left(\mathrm{m} \mathrm{s}^{-1}\right)$, surface and bottom meridional current velocity $\left[\mathrm{m} \mathrm{s}^{-1}\right]$, slope $\left[^{\circ}\right]$, and distance to shelf break $(\mathrm{m})$ (defined as $1000 \mathrm{~m}$ isobath).

Sea ice (except sea ice concentration), temperature, salinity and current velocity data were derived from the Finite Element Sea ice-Ocean Model (FESOM) as monthly mean values from January to May 1998 with a resolution of $5 \mathrm{~km} \times 5 \mathrm{~km}$ (Timmermann et al. 2009; Haid 2013; Haid and Timmermann 2013). FESOM is a physical ocean circulation model combined with a dynamic-hydrodynamic sea ice model, which proved to show good agreement with actual observations in terms of sea ice distribution and hydrography in the Southern Ocean (Timmermann et al. 2009; Haid 2013). Sea ice concentration was recorded by the Special Sensor Microwave/Imager (SSM/I) of the Defence Meteorological Satellite Program (DMSP) at the National Snow and Ice Data Center (NSIDC), Boulder, Colorado, USA with a resolution of $25 \mathrm{~km} \times 25 \mathrm{~km}$ (Meier et al. 2013, updated 2015; Peng et al. 2013). These were available as monthly mean ice concentrations ranging from $0 \%$ (open water) to $100 \%$ (closed ice cover) after being processed with the NASA-Team-Algorithm (Cavalieri et al. 1984; Peng et al. 2013). On the basis of the International Bathymetric Chart of the Southern Ocean (IBCSO; Arndt et al. 2013), Jerosch et al. (2015) derived a map on slope with a resolution of $0.5 \mathrm{~km} \times 0.5 \mathrm{~km}$ (doi:10.1594/PANGAEA.846871). Distance to shelf break (1000 $\mathrm{m}$ isobath) was calculated using the "Near" tool in ArcGIS. All environmental variables were available as GIS raster layers and were imported into ArcGIS.

\section{Data processing}

All hSSM filtered seal locations were assigned to the original environmental raster files from the respective sampling months. Then, the values from all environmental raster files were resampled by using the "Fishnet" tool in ArcGIS with a resolution of $5 \mathrm{~km} \times 5 \mathrm{~km}$, corresponding 
to the grid size of the FESOM raster, which contributed the majority of variables (10 of 13). Additionally, a $5 \mathrm{~km} \times 5 \mathrm{~km}$ resolution is a suitable determination for a seal's position, since Argos locations with low accuracy are prevalent in marine mammal studies (Vincent et al. 2002; Freitas et al. 2008). Thus, this new resolution allowed for a better reconciliation between seal locations and environmental parameters and also accounted for spatial autocorrelation of the tracking data, which mostly disappeared at a distance of greater than $5 \mathrm{~km}$.

The extent of all resampled raster layers was clipped to match the study area for Maxent analyses. It ranged from $65^{\circ} \mathrm{W}$ to $0^{\circ}$ and from $62^{\circ} \mathrm{S}$ to the edge of the shelf ice and the continent, respectively, and covered an area of $3,490,895 \mathrm{~km}^{2}$. This whole area is influenced by the Weddell Gyre (Schröder and Fahrbach 1999) and hence conforms oceanographically to the Weddell Sea. Furthermore, collinearity was assessed by calculating Pearson's correlation coefficients for all environmental variables in each month. Since the correlation coefficients of the examined set of variables did not exceed 0.71 , we incorporated all parameters in our full models. Finally, the resampled environmental raster files were converted from ArcGIS rasters to ASCII raster format for further usage in the Maxent software for species habitat modelling.

Prior to model building the seal location data were subsampled to diminish potential biases. All locations within a radius of $30 \mathrm{~km}$ around Drescher Inlet were removed to avoid a possible influence of clustered positions near the tagging site, as recommended by Edrén et al. (2010). In the following, only location data from February, March and April 1998 were used for modelling.

\section{Habitat modelling: set-up}

Maximum entropy (Maxent) is used to model species geographic distribution and suitable habitats on the basis of environmental conditions at known occurrence sites (Phillips et al. 2006). Maxent solely needs presence-only data (Elith et al. 2011) and is therefore applicable for opportunistic presence-only wildlife telemetry records. Since Maxent works well with small sample sizes $(n<100)$ (Phillips et al. 2006; Wisz et al. 2008) as well as imprecise locations (Graham et al. 2008), it is appropriate for the available satellite telemetry dataset. Only recently, several studies applied Maxent to model species distribution of marine top predators on the basis of satellite tracking data (e.g. Edrén et al. 2010; Friedlaender et al. 2011; Ballard et al. 2012). Additionally, it provides better results for species occurrence data that have not been collected systematically (e.g. by line transect methods) than many established modelling methods such as Generalized Linear Models (GLM), Generalized Additive
Models (GAM) and Genetic Algorithm for Rule-set Prediction (GARP) regarding predictive power (Elith et al. 2006, 2011; Phillips et al. 2006).

The programme Maxent (version 3.3.3 k; http://www.cs. princeton.edu/ schapire/maxent/; Phillips et al. 2004, 2006; Phillips and Dudík 2008) was run in sampleswith-data (SWD) format, i.e., the input file contained both species locations and values of all environmental variables at the specific location. As environmental layers we used 10,000 random background sample points of all environmental data raster instead of the original ASCII raster. This reduces the runtime of Maxent significantly without losing predictive power (Phillips and Dudík 2008). For each month, 20 model replicates were conducted using the autofeatures setting of Maxent, which supplies a good model performance in comparison with elaborated manual tuning (Phillips and Dudík 2008).

\section{Habitat modelling: evaluation}

By default Maxent randomly divides the species occurrence dataset in training and test data. While most data points are used to train the species distribution model, some remaining data evaluate the performance of the trained model (Phillips et al. 2006). For each model replicate Maxent randomly subsampled $20 \%$ of the location data for evaluation purposes (Table 3). Thus, the remaining $80 \%$ of species occurrence data were selected to create Maxent models in accordance with Edrén et al. (2010). Model performance was evaluated by creating receiver operating characteristic (ROC) curves using both test and training data. The area under the curve (AUC) gives information about the quality of model prediction. The AUC can range between 0 and 1 , where an area of 0.5 means a random prediction (Phillips et al. 2006). Thus, the closer AUC approaches 1 and the higher is the predictive power of the model (Fielding and Bell 1997).

In a first approach, Maxent indicated the influence of each environmental variable contributing to the model by a measure called permutation importance and identified the variable that mattered most concerning the seal distribution. As a second approach, a jackknife test was applied to analyse the relative importance of variables. On that account, Maxent generates and compares modelling results by using only a single environmental variable on the one hand and all variables except the single one on the other hand. By this means, the jackknife analysis reveals, how much a variable solely contributes to the model and how much gain is lost, when it is absent. Exploratory Maxent runs with the full set of 13 environmental variables revealed that slope, bottom zonal current velocity and bottom meridional current velocity did not contribute more than $5 \%$ to each monthly model as indicated by the 
Table 3 Total numbers of crabeater seal (Lobodon carcinophaga) locations for each month as well as portion of locations used by Maxent for either training or test (in parentheses) purposes. Average area under the curve (AUC) values of 20 replications on test data and standard deviation (SD) indicate model performance

\begin{tabular}{llll}
\hline Time period & Total locations & $\begin{array}{l}\text { Training (test) } \\
\text { locations }\end{array}$ & $\begin{array}{l}\text { Average } \\
\text { AUC } \pm \text { SD }\end{array}$ \\
\hline February 1998 & 784 & $628(156)$ & $0.933 \pm 0.005$ \\
March 1998 & 482 & $386(96)$ & $0.966 \pm 0.004$ \\
April 1998 & 251 & $201(50)$ & $0.971 \pm 0.006$
\end{tabular}

permutation importance. Thus, we omitted these parameters and performed all subsequent Maxent model runs with the remaining ten parameters (see Online Resource 1 for maps of environmental parameters and seal locations in corresponding months).

For February, March and April 1998, respectively, Maxent was run with 20 replications providing the logistic output, which supplies species probability of presence in a range between 0 and 1 (Phillips and Dudík 2008; Elith et al. 2011). All model results are given as the average of 20 replicates.

\section{Results}

Of the 15 SDRs that were deployed on crabeater seals, 12 provided extended transmission periods required for the modelling approach. The remaining three were excluded from further analyses (Table 1). Transmission failure might be due to technical malfunction of the SDR or damage of the antenna through sea ice impact as reported by Burns et al. (2004), or a premature shed-off of the device. Twelve SDRs provided data for a mean duration of $54.9 \pm 36.3$ days $(\bar{x} \pm \mathrm{SD}$; range $7-117$ days $)$, which ideally means until end of May 1998. In total, 3425 Argos locations were received, from which we obtained 2523 locations in consistent 6 -h time-steps by means of the hSSM.

\section{Movement behaviour and distribution}

The seals dispersed radially from Drescher Inlet shortly after tagging and covered large distances (Fig. 2). Ten seals explored the eastern and central Weddell Sea, while two animals moved far eastwards up to $45^{\circ} \mathrm{E}$ along the coast. The aforementioned individuals covered a distance of 4554 and $3796 \mathrm{~km}$ in 117 and 73 days, respectively (Table 1). The average track length was $1781 \pm 1367 \mathrm{~km}$ (range 201-4554 km). Occasionally, the seals stopped their travel to remain within a restricted area for a few days or even weeks. For instance, seal \#8 remained at the continental shelf break of the southern Weddell Sea (General
Belgrano Bank; $73^{\circ} \mathrm{S}, 48.5^{\circ} \mathrm{W}$ ) for more than a month. As identified by the hSSM, crabeater seals were in a transient state in $46.5 \%$ of their time, while being resident for $53.5 \%$ of their time (Fig. 3). A tendency for differences in track lengths and behavioural states between age classes was observed with non-adults covering greater distances and being more transient than adults, but these results could not be tested for significance due to insufficient sample sizes.

\section{Habitat modelling}

Maxent performed well in terms of generating species distribution models for crabeater seals from satellite telemetry data. AUC values were high in all 3 months (range 0.933-0.971) demonstrating that Maxent models differ distinctly from a random prediction; additionally, standard deviations were low indicating a high degree of uniformity among the replications (Table 3).

All three models predicted medium-to-high probabilities of presence in circumscribed areas of the study region. Generally, the eastern and southern Weddell Sea seems to be a suitable habitat for crabeater seals throughout the months (Fig. 4). The model predictions of February and March both emphasized the continental shelf break of the southern Weddell Sea as preferred habitat due to high probabilities of presence (Fig. 4a, b).

Throughout all 3 months, Maxent identified distance to shelf break and sea ice concentration as the most important variables for determining crabeater seal distribution (Table 4). The importance of these variables was generally confirmed by the respective jackknife tests (Online Resource 2). Additional variables with moderate overall importance to the models were meridional (February) and zonal surface velocity (March) as well as sea surface temperature (April).

We also created response curves displaying how the probability of presence changes with the value range of each environmental variable (Online Resource 3). Thus, preferred habitat conditions can be identified on the basis of the most important factors. Model predictions revealed that crabeater seals generally prefer a range of $400 \mathrm{~km}$ off 


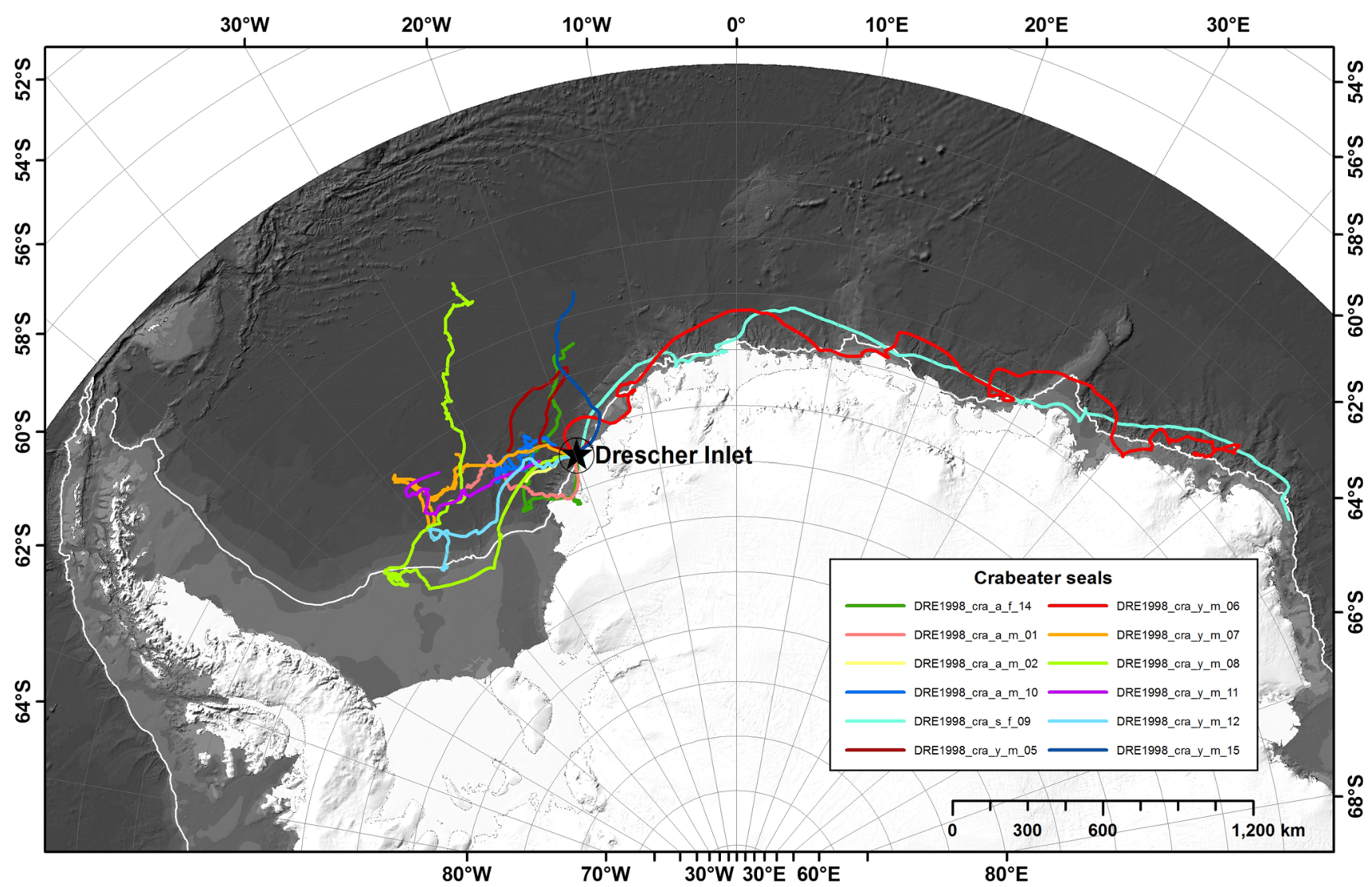

Fig. 2 Tracks of 12 crabeater seals (Lobodon carcinophaga) in the Weddell Sea dispersing from Drescher Inlet (star). Each coloured line represents an individual track. Bathymetry is indicated by various

the continental shelf break, but in April probability of presence is increasing with increasing distance. Predicted favoured sea ice concentrations varied considerably between months. Whereas probability of presence was highest for sea ice concentrations of $0 \%$ and slightly less for concentrations between 0 and $50 \%$ in February, the model predicted high probabilities of presence for medium sea ice concentrations (20-80\%) in March. An increase in crabeater seal occurrences was observed with increasing sea ice concentrations climaxing at around $90 \%$ in April.

\section{Diving behaviour}

Both dive depth and dive duration frequency displayed a unimodal pattern with the first bin being most prominent. Overall, $67.3 \pm 14.3 \%$ of all dives were shallower than $9 \mathrm{~m}$ and $45.4 \pm 16.6 \%$ were shorter than $1 \mathrm{~min}$. More than $90 \%$ of all dives took place to depths less than $51 \mathrm{~m}$ and did not last longer than $4 \mathrm{~min}$, while dives tended to become successively shallower and shorter from February to May 1998 (Fig. 5). The maximum dive depth was on average $248 \pm 141 \mathrm{~m}$. The overall deepest dive was performed by seal \#9 down to $776 \mathrm{~m}$. shades of grey $($ light $=$ shallow, dark $=$ deep $)$. The white line shows the $1000 \mathrm{~m}$ isobath defined as continental shelf break

\section{Discussion}

\section{Movement and distribution}

The present study supports the notion that crabeater seals are highly mobile covering vast distances in a relatively short time. Similar maximum track lengths $(3875 \mathrm{~km})$ were reported for crabeater seals tagged off Queen Maud Land within the Weddell Sea (Nordøy et al. 1995). This high mobility could also explain the homogeneous genetic population structure in this species around Antarctica (Davis et al. 2008). In particular, the extensive tracks of the two subadult seals in this study emphasize the potential for a pronounced level of gene flow between different areas around the continent, as suggested by Davis et al. (2008).

\section{Limitations of the habitat modelling approach}

We implemented a Maxent modelling analysis to identify suitable habitats for crabeater seals within the Weddell Sea and to discern which environmental factors primarily influence the seals' distribution. For a reasonable species distribution modelling the distribution and density of the 


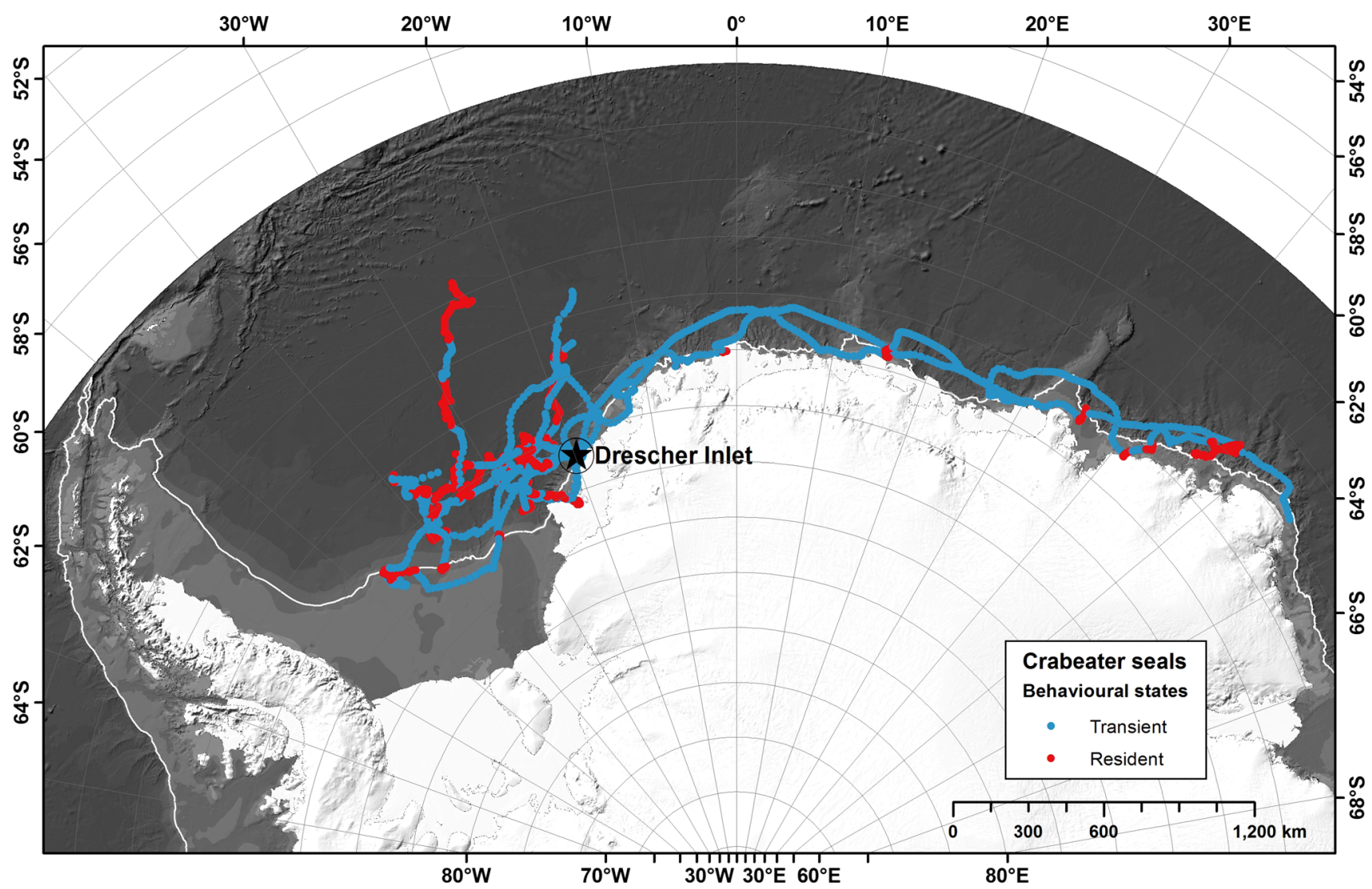

Fig. 3 Behavioural state estimation of crabeater seals (Lobodon carcinophaga) as obtained from a hierarchical state-space model (hSSM). Blue dots represent locations, where the animal was

response parameter (presence of crabeater seals) as well as the consideration of relevant environmental parameters and their resolution are essential. By using the available data, we realize that we present a simplified assumption, since the model does not cover the complexity of the ecological system of the Weddell Sea. For example, we lacked biotic information to consider, e.g. contemporaneous information on krill and chlorophyll a distribution. Furthermore, we could not take interactive effects between the seals and their biotic and abiotic environment into account. In this sense, we had to consider the specimens as independent entities.

In our analyses, we aimed at describing the large-scale temporal and spatial changes in environmental features and the dynamic response of crabeater seals to this changing environment. However, synoptic environmental data averaged over larger time scales do not necessarily reflect the conditions experienced by the animals, leading to a potential mismatch of satellite tracking data and environmental data. In this case, an assessment of fine-scale habitat use was not feasible, since sample sizes were too low and the study area and animals' dispersal too large to calculate reliable models on a daily or weekly basis. Nowadays, modern tracking technologies are able to collect in situ estimated to be in a transient state, while red dots indicate locations of resident movements and area-restricted search

environmental information, which provide a higher resolution to study an animal's habitat use and foraging behaviour (see review by Costa et al. 2012).

We successfully generated habitat models for crabeater seals from satellite telemetry data with relatively strong predictive power, as indicated by high AUC values. By choosing a different approach, Raymond et al. (2014) were not able to model crabeater seal habitats in eastern Antarctica, which might demonstrate the strength of Maxent as a powerful habitat modelling technique. On the other hand, presence-only models like Maxent are intrinsically biased and certain limitations have to be considered. For example, extrapolation to other study areas or potential future climatic scenarios can be problematic resulting in large predicted values (Phillips et al. 2006). Another issue concerns the AUC value as a measure of model quality. If absences are selected from a very large study area compared to the extent of the actual sample, AUC values can easily become high with presence-only data (Wisz et al. 2008). This might partly explain the generally high AUC values in our study; however, when using different study area extents, AUC values did not change considerably. The Maxent modelling results also indicate that overfitting may 
Fig. 4 Probability of presence of crabeater seals (Lobodon carcinophaga) in the Weddell Sea modelled by Maxent for February (a), March (b) and April 1998 (c). Blue indicates areas with very low probability of presence, whereas regions in red represent "hot spots".

Yellow corresponds to areas, which exhibit typical habitat conditions for this seal species. Bathymetry is indicated by white contour lines. Presence locations of crabeater seals, which were relevant for the respective models, are given as black crosses
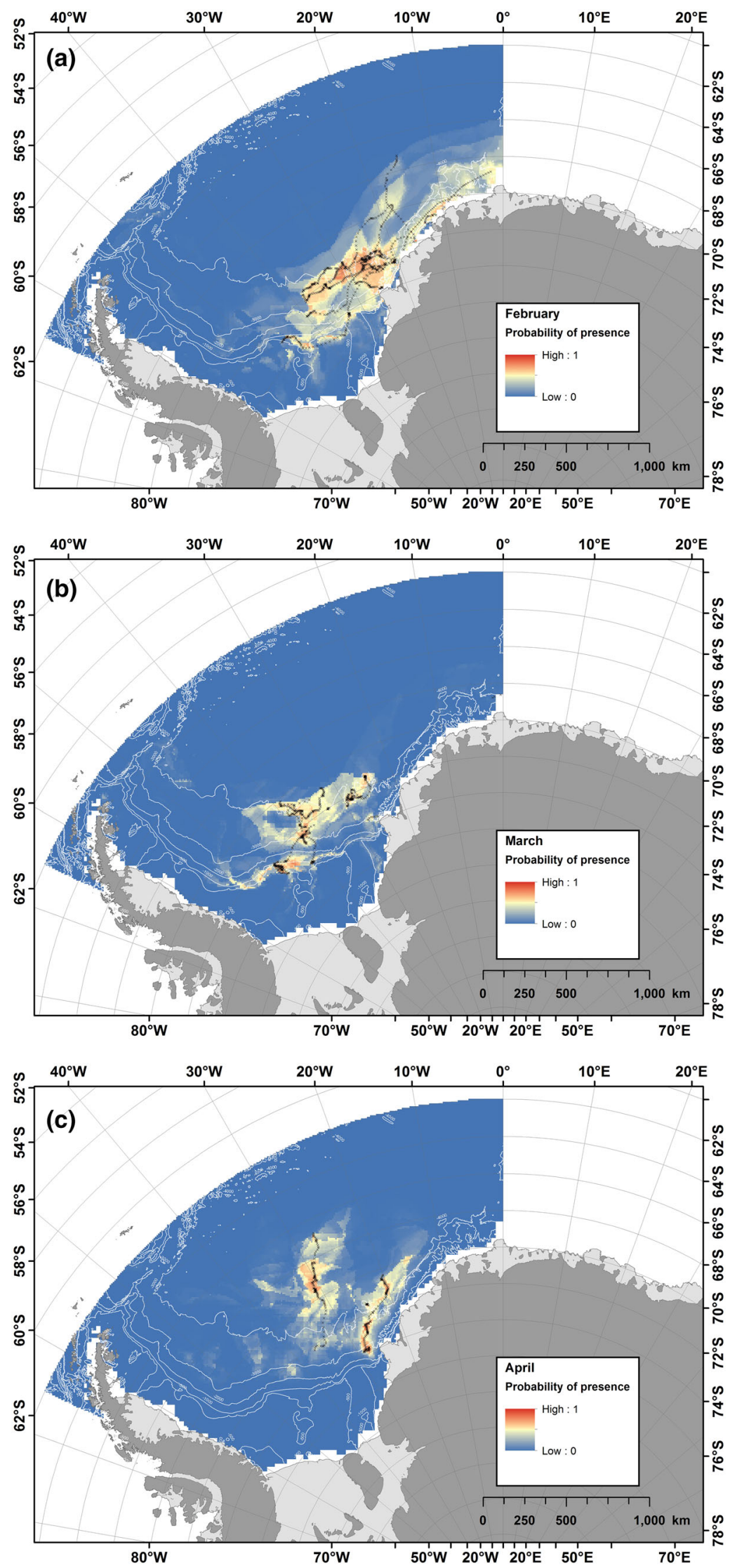
be an issue, which occurs when the model prediction follows an environmental gradient too closely. As a potential solution, a recently developed ensemble modelling approach may be viable, which implements a set of different modelling techniques (e.g. GLM, GAM, random forests, Maxent) and combines these modelling results to a consensus prediction (Thuiller et al. 2009).

Our heterogeneous sample group of seals consisted of animals of different age classes and sexes, which was the result of the opportunistic tagging of crabeater seals at the Drescher Inlet. Due to limited sample sizes, we could not investigate the influence of these intrinsic factors on the distribution and habitat use of crabeater seals. However, despite the aforementioned limitations, we observed a tendency of the non-adult seals to be more transient and to cover greater distances than the adults. It is likely that foraging strategies differ between age classes, due to varying levels of at-sea experience and physiological abilities as shown for other phocid seals (e.g. Field et al. 2005 for southern elephant seals). Moreover, the SDRs transmitted data for various durations ranging between 7 and 117 days, so that individuals providing data for longer periods contributed more to the model than others. Nevertheless, we pooled the data of all animals for our analyses, since the purpose of our study was to provide an overall picture of suitable habitats and ecological drivers, which influenced the habitat use of crabeater seals in the Weddell Sea in 1998.

Due to these limitations, the dataset does not allow an in-depth analysis of each environmental factor contributing to the mode. We therefore focussed our interpretation of the modelling results on the most important findings and variables.

\section{Habitat modelling and distance to continental shelf break}

Distance to the shelf break was one of the two most important parameters influencing crabeater seal
Fig. 5 Dive depth (a) and dive duration (b) of crabeater seals (Lobodon carcinophaga) split into individual months; $n=$ number of seals still transmitting during the corresponding month. Bars represent mean frequency distribution; error bars (whisker caps) show standard error of the mean (SEM)

distribution. Our model analyses predicted high probabilities of presence within $400 \mathrm{~km}$ off the shelf break. This favoured region corresponds to water depths between 1000 and $4000 \mathrm{~m}$ in the Weddell Sea. Consistently, tagged crabeater seals in eastern Antarctica usually remained within $600 \mathrm{~km}$ off the shelf break and inhabited areas between 2000 and $4600 \mathrm{~m}$ depth in the post-breeding season (Wall et al. 2007). Aerial line transect methods also showed that crabeater seals were mainly associated with water depths around $2500 \mathrm{~m}$, but rarely present in areas deeper than $4000 \mathrm{~m}$ (Southwell et al. 2005).

\section{Habitat modelling and sea ice concentration}

Our analyses revealed that sea ice concentration was the second most important parameter concerning species distribution. The importance of sea ice concentration was also emphasized in other studies investigating crabeater seal distribution (e.g. Joiris 1991; Bester et al. 2002; Ballard et al. 2012). However, these studies were based on observations of hauled-out seals, which are only visible on ice floes and thus inferences on habitat preferences are inherently biased. Satellite tracking allows a more objective approach to investigate an animal's habitat use and may distinguish between haul-out and foraging areas. For February, our models predicted a high probability of presence of crabeater seals in ice-free waters. This was confirmed by the observation that most seal locations were situated in open waters at that time (Online Resource 1.1c). This is in contrast to the aforementioned general conception regarding crabeater seals as typical pack ice inhabitants that preferably avoid open waters (Joiris 1991; Nordøy et al. 1995; Ackley et al. 2003; Burns et al. 2004;
Table 4 Permutation importance, a relative measure of variable contributions to the respective Maxent models in February, March and April 1998 , is given as percentage

\begin{tabular}{lccc}
\hline Environmental variable & February $(\%)$ & March $(\%)$ & April (\%) \\
\hline Distance to shelf break & $\mathbf{4 4 . 6}$ & $\mathbf{2 2 . 8}$ & $\mathbf{3 6 . 1}$ \\
Sea ice freezing rate & 0.5 & 0.4 & 4.0 \\
Sea ice thickness & 1.0 & 0.1 & 9.1 \\
Sea ice concentration & $\mathbf{1 0 . 3}$ & $\mathbf{3 6 . 8}$ & $\mathbf{1 0 . 2}$ \\
Salinity, bottom & 0.9 & 6.6 & 0.6 \\
Salinity, surface & 1.9 & 6.4 & 1.6 \\
Water temperature, bottom & 9.4 & 7.5 & 4.9 \\
Water temperature, surface & 8.3 & 7.2 & 21.0 \\
Velocity, meridional, surface & 21.9 & 2.5 & 8.4 \\
Velocity, zonal, surface & 1.3 & 9.7 & 4.1 \\
\hline
\end{tabular}

The most important contributors throughout all three models are highlighted in bold 

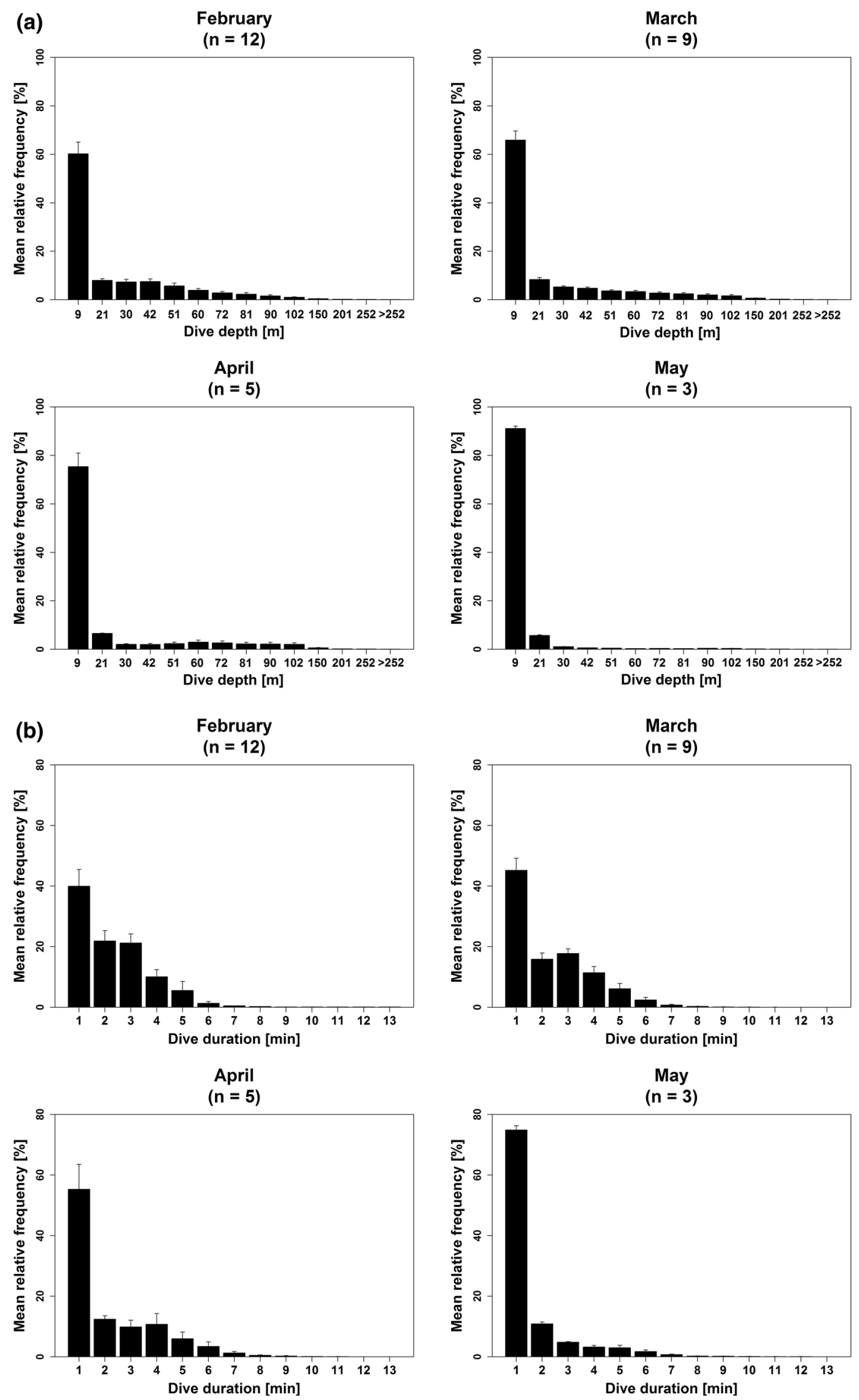
Ballard et al. 2012). However, tagged seals in eastern Antarctica also spent $14.4 \%$ of their time in ice-free areas during the post-breeding season, after mid-November (Wall et al. 2007). Apparently, crabeater seals frequent open waters more often than previously assumed from visual observations, especially during summer months.

Certainly, one reason for the extensive use of open water in this study was the comparatively low sea ice cover and extent during summer 1998. While a well-circumscribed pack ice field remained in the western Weddell Sea, pack ice was virtually absent in the eastern Weddell Sea, likely due to a strong El Niño event (Bester and Odendaal 2000; Cavalieri and Parkinson 2008; Online Resource 1.1c). Bester and Odendaal (2000) conducted helicopter seal censuses during the EASIZ II expedition in synchrony to our tagging work. They concluded that their very high density estimate was a result of the unusually low sea ice extent, since seals concentrated on the remaining ice floes for hauling out (Bester and Odendaal 2000). However, we could not detect any differences in distributional behaviour (e.g. searching for sea ice, remaining on residual fast ice) in comparison with a year with normal ice conditions in the same area (Nordøy et al. 1995). In both cases, the seals exhibited an extensive dispersal into the Weddell Sea. The still transmitting seals migrated northwards in March following the extending ice edge. During that period, these seals for the first time occupied regions with higher ice concentrations $(>50 \%)$. Both northward migration and the occurrence within pack ice in autumn were again consistent with results from Nordøy et al. (1995) in the Weddell Sea. The models for March and April reflected these changes in habitat preferences concerning sea ice concentration. Apparently, crabeater seals can cope well with open water conditions and do not rely on heavy pack ice in late summer.

\section{Foraging implications}

The predicted suitable habitat preferences of crabeater seals correspond very well to the seasonal life cycle and distribution of their primary prey, the Antarctic krill Euphausia superba (King 1961; Øritsland 1977; Lowry et al. 1988; Hückstädt et al. 2012). However, it has been suggested that crystal krill (Euphausia crystallorophias) forms an important component of the crabeater seal's diet as well, especially in the high-Antarctic ecosystem (Siniff et al. 2008), and a study by Dubbels et al. (1985) showed that crabeater seals may also feed extensively on the pelagic fish Pleuragramma antarctica. The latter study was based on six stomach samples of crabeater seals collected close to the east coast of the Weddell Sea, our study area, in summer. Intestines of crabeater seals taken further offshore in the Weddell Sea were filled with adult Antarctic krill E. superba (Erickson 1984; Mårtensson et al. 1994), whereas crystal krill E. crystallorophias was found in at least two crabeater seal stomachs on the southern Weddell Sea continental shelf (Drescher and Plötz 1983). Both adult $P$. antarctica and adult crystal krill mainly inhabit the shallow Antarctic shelf areas (Hubold 1984; Boysen-Ennen and Piatkowski 1988; Boysen-Ennen et al. 1991). Since the instrumented seals in this study mostly remained off the continental shelf break, which is reflected by the identified suitable habitats, and the majority of the adult Antarctic krill population inhabits deeper oceanic areas (BoysenEnnen et al. 1991; Atkinson et al. 2008), we assume a rather Antarctic krill-based diet of our tagged crabeater seals.

Although the life cycle of the Antarctic krill is closely associated with the sea ice regime, it inhabits ice-free waters as well, particularly in summer and autumn (Flores et al. 2011, 2012), when krill swarms feed on phytoplankton in surface waters. The overwintering strategy of adult Antarctic krill is quite complex and consists of various mechanisms, including a reduced feeding activity, utilization of lipid stores, shrinkage and a switch in food sources (Quetin and Ross 1991; Hagen et al. 2001; Meyer 2012). During the dark season, adult krill usually migrates to deeper water layers below $200 \mathrm{~m}$ (Lawson et al. 2004; Siegel 2005; Taki et al. 2005), but they may also concentrate directly under the sea ice in locally very high densities, especially in oceanic areas (Marschall 1988; Plötz et al. 1991; Flores et al. 2011, 2012). This complex seasonal migration pattern of krill may explain the differences in distributional behaviour and habitat preferences of crabeater seals, as the season progressed. In late summer/early autumn, the tagged seals extensively travelled through icefree waters, whereas towards late autumn they migrated northwards inhabiting heavy pack ice areas. Thus, habitat preferences of crabeater seals are seasonally dynamic concerning sea ice concentration and appear to follow the distribution of the Antarctic krill.

Diving behaviour was generally characterized by short and shallow dives. An average of $67 \%$ of all dives were shallower than $9 \mathrm{~m}$, and more than $90 \%$ of all dives were shorter than $4 \mathrm{~min}$. This reflects the typical summer and autumn diving behaviour of crabeater seals, as recorded in other studies (Bengtson and Stewart 1992; Nordøy et al. 1995; Wall et al. 2007). Usually, crabeater seals use the upper $50 \mathrm{~m}$ of the water column and do not dive longer than $5 \mathrm{~min}$. This is in accordance with the vertical distribution of the Antarctic krill, which occurs in the ocean surface layer, generally within the upper 50-150 m, during summer (Lascara et al. 1999; Siegel 2005; Taki et al. 2005), whereas other potential abundant prey species (e.g. adult $P$. antarctica) are usually found below $150 \mathrm{~m}$ (Hubold 1984; O’Driscoll et al. 2011). Moreover, Flores 
et al. (2012) reported that adult krill was very abundant in the upper $2 \mathrm{~m}$ of the water column below the sea ice and in open surface waters during the summer season. Thus, crabeater seals do not need to dive deeper to reach their primary prey, in fact, they synchronize their foraging activities with the diel vertical migration of krill and forage at night, when krill is closest to the surface (Bengtson and Stewart 1992; Bengtson and Cameron 2004). As a result, the seals exhibit a diving pattern that is energetically very efficient. Other endothermic krill predators, e.g. Antarctic fur seals, leopard seals and various penguin species, show similar diving patterns (Croxall et al. 1985, 1988; Bengtson et al. 1993; Nordøy and Blix 2009). Although deep dives reflected only a minor fraction of the diving activities, it is noteworthy that the deepest dive in our study $(776 \mathrm{~m})$ exceeded the reported maximum dive depth of $713 \mathrm{~m}$ for crabeater seals (Burns et al. 2004).

Our descriptive dive analyses indicated that the diving behaviour of crabeater seals in the eastern Weddell Sea showed seasonal differences with dives becoming shallower and shorter between February and May, as also reported by Nordøy et al. (1995) for the period between February and June. When the sea ice extent in the Weddell Sea is expanding again from March onwards (Schwegmann 2012), adult krill concentrates at the underside of sea ice as an overwintering strategy (Marschall 1988; Smetacek et al. 1990; Flores et al. 2012). Although sea ice can be highly structured and may offer protection from predators, krill seems to be largely accessible to its predators, as indicated by the seals' change in diving behaviour towards winter.

Compared to our study in the Weddell Sea, Burns et al. (2004) reported pronounced differences in distributional and diving behaviour from the western Antarctic Peninsula. In winter and spring, tagged crabeater seals remained above the continental shelf at water depths between 50 and $450 \mathrm{~m}$ with high sea ice concentrations, avoiding deeper regions. Furthermore, seals at the western Antarctic Peninsula dived deeper $(\bar{x}=92 \mathrm{~m})$ and longer $(\bar{x}=5.26 \mathrm{~min})$ compared to all other studies. These behavioural differences may be explained by the distribution of Antarctic krill within this region. During winter, adult krill migrates back onto the continental shelf of the Antarctic Peninsula and overwinters inshore in deeper layers $(>150 \mathrm{~m})$, which was confirmed by acoustic backscattering and trawling samples during autumn and winter (Burns et al. 2004; Lawson et al. 2004, 2008; Siegel 2005). Therefore, crabeater seals simply had to dive deeper to reach their primary prey. As a compensation, the seals aggregated locally, where sea ice, bathymetry and prey availability were particularly suitable (Burns et al. 2004, 2008). Since no further study is available about the diving and foraging behaviour of crabeater seals in other regions during winter, geographic differences between study areas cannot be excluded. For instance, the continental shelf surrounding the Antarctic Peninsula is broad and apparently provides a suitable habitat for crabeater seals regarding, e.g. prey availability (Burns et al. 2004; Lawson et al. 2004; Friedlaender et al. 2011). In contrast, the eastern part of the Weddell Sea and other areas in eastern Antarctica are characterized by a narrow continental shelf, which probably provides less favourable foraging conditions during winter, forcing crabeater seals to follow the extending ice edge off the shelf break.

The extreme dependency of crabeater seals on suitable habitat conditions (mainly defined through distance to shelf break and sea ice concentration) and assumingly on the Antarctic krill as their almost mono-specific prey is clearly highlighted in this study. The eastern and southern Weddell Sea ecosystem is not yet impacted by climate change (but see Hellmer et al. 2012) and an intensified krill fishery; however, in the Antarctic Peninsula area such developments already appear to reduce potential crabeater seal habitat and diminish krill stocks (Atkinson et al. 2004; Forcada et al. 2012). Crabeater seals are a key component of the Antarctic ecosystem and their vulnerability requires further intensive research with focus upon synergistic anthropogenic effects on this species, e.g. concerning decreasing sea ice cover and declining krill populations.

Acknowledgments We thank captain Ernst-Peter Greve and the crew of RV Polarstern as well as chief pilot Uwe Lahrmann and the team of the helicopter service Wasserthal and our colleagues of the Department of Logistics of the Alfred Wegener Institute for their excellent support during PS48 (ANT-XV/3). We are also grateful to Ralph Timmermann, who provided the FESOM data that have been used in the Maxent analyses. Furthermore, we would like to thank three anonymous reviewers for their helpful comments to improve the manuscript.

Open Access This article is distributed under the terms of the Creative Commons Attribution 4.0 International License (http://crea tivecommons.org/licenses/by/4.0/), which permits unrestricted use, distribution, and reproduction in any medium, provided you give appropriate credit to the original author(s) and the source, provide a link to the Creative Commons license, and indicate if changes were made.

\section{References}

Ackley SF, Bengtson JL, Boveng P, Castellini M, Daly KL, Jacobs S, Kooyman GL, Laake J, Quetin L, Ross R, Siniff DB, Stewart BS, Stirling I, Torres J, Yochem PK (2003) A top-down multidisciplinary study of the structure and function of the pack-ice ecosystem in the eastern Ross Sea, Antarctica. Polar Rec 39:219-230

Arndt JE, Schenke HW, Jakobsson M, Nitsche FO, Buys G, Goleby B, Rebesco M, Bohoyo F, Hong J, Black J, Greku R, Udintsev G, Barrios F, Reynoso-Peralta W, Taisei M, Wigley R (2013) The International Bathymetric Chart of the Southern Ocean (IBCSO) version 1.0 - a new bathymetric compilation covering circumAntarctic waters. Geophys Res Lett 40:3111-3117 
Arntz WE, Gutt J (1998) The Expedition ANTARKTIS XV/3 (EASIZ II) of RV "Polarstern" in 1998. Ber Polarforsch 301, 244 pp

Atkinson A, Siegel V, Pakhomov EA, Rothery P (2004) Long-term decline in krill stock and increase in salps within the Southern Ocean. Nature 432:100-103

Atkinson A, Siegel V, Pakhomov EA, Rothery P, Loeb V, Ross RM, Quetin LB, Schmidt K, Fretwell P, Murphy EJ, Tarling GA, Fleming AH (2008) Oceanic circumpolar habitats of Antarctic krill. Mar Ecol Prog Ser 362:1-23

Ballard G, Jongsomjit D, Veloz SD, Ainley DG (2012) Coexistence of mesopredators in an intact polar ocean ecosystem: the basis for defining a Ross Sea marine protected area. Biol Conserv $156: 72-82$

Bengtson JL, Cameron MF (2004) Seasonal haulout patterns of crabeater seals (Lobodon carcinophaga). Polar Biol 27:344-349

Bengtson JL, Laws RM (1985) Trends in crabeater seal age at maturity: an insight into Antarctic marine interactions. In: Siegfried WR, Condy PR, Laws RM (eds) Antarctic nutrient cycles and food webs. Springer, Berlin, pp 669-675

Bengtson JL, Siniff DB (1981) Reproductive aspects of female crabeater seals (Lobodon carcinophagus) along the Antarctic Peninsula. Can J Zool 59:92-102

Bengtson JL, Stewart BS (1992) Diving and haulout behavior of crabeater seals in the Weddell Sea, Antarctica, during March 1986. Polar Biol 12:635-644

Bengtson JL, Croll DA, Goebel ME (1993) Diving behaviour of chinstrap penguins at Seal Island. Antarct Sci 5:9-15

Bester MN, Odendaal PN (2000) Abundance and distribution of Antarctic pack ice seals in the Weddell Sea. In: Davison W, Howard-Williams C, Broady P (eds) Antarctic ecosystems: models for wider ecological understanding. Caxton Press, Christchurch, pp 51-55

Bester MN, Ferguson JWH, Jonker FC (2002) Population densities of pack ice seals in the Lazarev Sea, Antarctica. Antarct Sci 14:123-127

Bornemann H, Plötz J (2006) Immobilisation dose rates for crabeater seals during expedition DRE1998. doi:10.1594/PANGAEA. 438929

Bornemann H, Mohr E, Plötz J, Krause G (1998) The tide as zeitgeber for Weddell seals. Polar Biol 20:396-403

Boysen-Ennen E, Piatkowski U (1988) Meso- and macrozooplankton communities in the Weddell Sea, Antarctica. Polar Biol 9:17-35

Boysen-Ennen E, Hagen W, Hubold G, Piatkowski U (1991) Zooplankton biomass in the ice-covered Weddell Sea, Antarctica. Mar Biol 111:227-235

Burns JM, Costa DP, Fedak MA, Hindell MA, Bradshaw CJA, Gales NJ, McDonald B, Trumble SJ, Crocker DE (2004) Winter habitat use and foraging behavior of crabeater seals along the Western Antarctic Peninsula. Deep-Sea Res II 51:2279-2303

Burns JM, Hindell MA, Bradshaw CJA, Costa DP (2008) Fine-scale habitat selection of crabeater seals as determined by diving behavior. Deep-Sea Res II 55:500-514

Cavalieri DJ, Parkinson CL (2008) Antarctic sea ice variability and trends, 1979-2006. J Geophys Res 113:C07004. doi:10.1029/ 2007JC004564

Cavalieri DJ, Gloersen P, Campbell WJ (1984) Determination of sea ice parameters with the NIMBUS 7 SMMR. J Geophys Res 89:5355-5369

Costa DP, Breed GA, Robinson PW (2012) New insights into pelagic migrations: implications for ecology and conservation. Annu Rev Ecol Evol Syst 43:73-96

Croxall JP, Everson I, Kooyman GL, Ricketts C, Davis RW (1985) Fur seal diving behaviour in relation to vertical distribution of krill. J Anim Ecol 54:1-8
Croxall JP, Davis RW, O'Connell MJ (1988) Diving patterns in relation to diet of gentoo and macaroni penguins at South Georgia. Condor 90:157-167

Davis CS, Stirling I, Strobeck C, Coltman DW (2008) Population structure of ice-breeding seals. Mol Ecol 17:3078-3094

Drescher E, Plötz J (1983) Biologie der Meeressäuger und Seevögel. In: Hempel G (ed) Die Expedition ANTARKTIS-I mit FS "Polarstern" 1982/83. Ber Polarforsch 14:44-47

Dubbels R, Graefe M, Limberger D, Plötz J (1985) Studies on seals and seabirds. In: Hempel G (ed) Die Expedition Antarktis III mit FS "Polarstern" 1984/85. Ber Polarforsch 25:133-137

Edrén SMC, Wisz MS, Teilmann J, Dietz R, Söderkvist J (2010) Modelling spatial patterns in harbour porpoise satellite telemetry data using maximum entropy. Ecography 33:698-708

Elith J, Graham CH, Anderson RP, Dudík M, Ferrier S, Guisan A, Hijmans RJ, Huettmann F, Leathwick JR, Lehmann A, Li J, Lohmann LG, Loiselle BA, Manion G, Moritz C, Nakamura M, Nakazawa Y, Overton JMCC, Peterson AT, Phillips SJ, Richardson KS, Scachetti-Pereira R, Schapire RE, Soberón J, Williams S, Wisz MS, Zimmermann NE (2006) Novel methods improve prediction of species' distributions from occurrence data. Ecography 29:129-151

Elith J, Phillips SJ, Hastie T, Dudík M, Chee YE, Yates CJ (2011) A statistical explanation of MaxEnt for ecologists. Divers Distrib 17:43-57

Erickson AW (1984) Aerial census of seals, whales, and penguins in the pack-ice of the northwestern Weddell Sea, November 1983. Antarct J US 19:121-124

Erickson AW, Hanson MB (1990) Continental estimates and population trends of Antarctic ice seals. In: Kerry KR, Hempel G (eds) Antarctic ecosystems: ecological change and conservation. Springer, Berlin, pp 253-264

Field IC, Bradshaw CJA, Burton HR, Sumner MD, Hindell MA (2005) Resource partitioning through oceanic segregation of foraging juvenile southern elephant seals (Mirounga leonina). Oecologia 142:127-135

Fielding AH, Bell JF (1997) A review of methods for the assessment of prediction errors in conservation presence/absence models. Environ Conserv 24:38-49

Flores H, van Franeker JA, Cisewski B, Leach H, Van de Putte AP, Meesters E, Bathmann U, Wolff WJ (2011) Macrofauna under sea ice and in the open surface layer of the Lazarev Sea, Southern Ocean. Deep-Sea Res II 58:1948-1961

Flores H, van Franeker JA, Siegel V, Haraldsson M, Strass V, Meesters E, Bathmann U, Wolff WJ (2012) The association of Antarctic krill Euphausia superba with the under-ice habitat. PLoS ONE. doi:10.1371/journal.pone.0031775

Forcada J, Trathan PN, Boveng PL, Boyd IL, Burns JM, Costa DP, Fedak M, Rogers TL, Southwell CJ (2012) Responses of Antarctic pack-ice seals to environmental change and increasing krill fishing. Biol Conserv 149:40-50

Freitas C, Lydersen C, Fedak MA, Kovacs KM (2008) A simple new algorithm to filter marine mammal Argos locations. Mar Mammal Sci 24:315-325

Friedlaender AS, Johnston DW, Fraser WR, Burns JM, Halpin PN, Costa DP (2011) Ecological niche modeling of sympatric krill predators around Marguerite Bay, Western Antarctic Peninsula. Deep-Sea Res II 58:1729-1740

Graham CH, Elith J, Hijmans RJ, Guisan A, Peterson AT, Loiselle BA, NCEAS Predicting Species Distributions Working Group (2008) The influence of spatial errors in species occurrence data used in distribution models. J Appl Ecol 45:239-247

Hagen W, Kattner G, Terbrüggen A, Van Vleet ES (2001) Lipid metabolism of the Antarctic krill Euphausia superba and its ecological implications. Mar Biol 139:95-104 
Haid V (2013) Coastal polynyas in the southwestern Weddell Sea: Surface fluxes, sea ice production and water mass modification. Dissertation, University of Bremen, $160 \mathrm{pp}$

Haid V, Timmermann R (2013) Simulated heat flux and sea ice production at coastal polynyas in the southwestern Weddell Sea. J Geophys Res Oceans. doi:10.1002/jgrc.20133

Hellmer HH, Kauker F, Timmermann R, Determann J, Rae J (2012) Twenty-first-century warming of a large Antarctic ice-shelf cavity by a redirected coastal current. Nature 485:225-228

Hubold G (1984) Spatial distribution of Pleuragramma antarcticum (Pisces: Nototheniidae) near the Filchner- and Larsen Ice Shelves (Weddell Sea/Antarctica). Polar Biol 3:231-236

Hückstädt LA, Burns JM, Koch PL, McDonald BI, Crocker DE, Costa DP (2012) Diet of a specialist in a changing environment: the crabeater seal along the western Antarctic Peninsula. Mar Ecol Prog Ser 455:287-301

Jerosch K, Kuhn G, Krajnik I, Scharf FK, Dorschel B (2015) A geomorphological seabed classification for the Weddell Sea. Mar Geophys Res, Antarctica. doi:10.1007/s11001-015-9256-x

Joiris CR (1991) Spring distribution and ecological role of seabirds and marine mammals in the Weddell Sea, Antarctica. Polar Biol $11: 415-424$

Jonsen I (2016) Joint estimation over multiple individuals improves behavioural state inference from animal movement data. Sci Rep. doi:10.1038/srep20625

Jonsen I, Basson M, Bestley S, Bravington MV, Patterson TA, Pedersen MW, Thomson R, Thygesen UH, Wotherspoon SJ (2013) State-space models for bio-loggers: a methodological road map. Deep-Sea Res II 88-89:34-46

King JE (1961) The feeding mechanism and jaws of the crabeater seal (Lobodon carcinopagus). Mammalia 25:462-466

Lascara CM, Hofmann EE, Ross RM, Quetin LB (1999) Seasonal variability in the distribution of Antarctic krill, Euphausia superba, west of the Antarctic Peninsula. Deep-Sea Res II 46:951-984

Laws RM, Baird A, Bryden MM (2003) Size and growth of the crabeater seal Lobodon carcinophagus (Mammalia: Carnivora). J Zool 259:103-108

Lawson GL, Wiebe PH, Ashjian CJ, Gallager SM, Davis CS, Warren JD (2004) Acoustically-inferred zooplankton distribution in relation to hydrography west of the Antarctic Peninsula. DeepSea Res II 51:2041-2072

Lawson GL, Wiebe PH, Ashijan CJ, Stanton TK (2008) Euphausiid distribution along the Western Antarctic Peninsula-Part B: distribution of euphausiid aggregations and biomass, and associations with environmental features. Deep-Sea Res II 55:432-454

Lowry LF, Testa JW, Calvert W (1988) Notes on winter feeding of crabeater and leopard seals near the Antarctic Peninsula. Polar Biol 8:475-478

Marschall H-P (1988) The overwintering strategy of Antarctic krill under the pack-ice of the Weddell Sea. Polar Biol 9:129-135

Mårtensson P-E, Nordøy ES, Blix AS (1994) Digestibility of krill (Euphausia superba and Thysanoessa sp.) in minke whales (Balaenoptera acutorostrata) and crabeater seals (Lobodon carcinophagus). Br J Nutr 72:713-716

Meier W, Fetterer F, Savoie M, Mallory S, Duerr R, Stroeve J (2013, updated 2015) NOAA/NSIDC Climate Data Record of Passive Microwave Sea Ice Concentration, Version 2. Boulder, Colorado USA. NSIDC: National Snow and Ice Data Center. doi: http://dx. doi.org/10.7265/N55M63M1. Accessed: 15 April 2016

Meyer B (2012) The overwintering of Antarctic krill, Euphausia superba, from an ecophysiological perspective. Polar Biol 35:15-37

Nicol S (2006) Krill, currents, and sea ice: Euphausia superba and its changing environment. Bioscience 56:111-120
Nordøy ES, Blix AS (2009) Movements and dive behaviour of two leopard seals (Hydrurga leptonyx) off Queen Maud Land, Antarctica. Polar Biol 32:263-270

Nordøy ES, Folkow LP, Blix AS (1995) Distribution and diving behaviour of crabeater seals (Lobodon carcinophagus) off Queen Maud Land. Polar Biol 15:261-268

O’Driscoll RL, Macauly GJ, Gauthier S, Pinkerton M, Hanchet S (2011) Distribution, abundance and acoustic properties of Antarctic silverfish (Pleuragramma antarcticum) in the Ross Sea. Deep-Sea Res II 58:181-195

Øritsland T (1977) Food consumption of seals in the Antarctic pack ice. In: Llano GA (ed) Adaptations within Antarctic ecosystems. Smithsonian Institute, Washington, pp 749-768

Peng G, Meier WN, Scott DJ, Savoie MH (2013) A long-term and reproducible passive microwave sea ice concentration data record for climate studies and monitoring. Earth Syst Sci Data 5:311-318

Phillips SJ, Dudík M (2008) Modeling of species distributions with Maxent: new extensions and a comprehensive evaluation. Ecography 31:161-175

Phillips SJ, Dudik M, Schapire RE (2004) A maximum entropy approach to species distribution modeling. In: Proceedings of 21st International Conference on Machine Learning. ACM Press, New York, pp 655-662

Phillips SJ, Anderson RP, Schapire RE (2006) Maximum entropy modeling of species geographic distributions. Ecol Model 190:231-259

Plötz J, Weidel H, Bersch M (1991) Winter aggregations of marine mammals and birds in the north-eastern Weddell Sea pack ice. Polar Biol 11:305-309

Quetin LB, Ross RM (1991) Behavioural and physiological characteristics of the Antarctic krill, Euphausia superba. Amer Zool 31:49-63

R Core Team (2014) R: a language and environment for statistical computing. R Foundation for Statistical Computing, Vienna, Austria. http://www.R-project.org/

Raymond B, Lea M-A, Patterson T, Andrews-Goff V, Sharples R, Charrassin J-B, Cottin M, Emmerson L, Gales N, Gales R, Goldsworthy SD, Harcourt R, Kato A, Kirkwood R, Lawton K, Ropert-Coudert Y, Southwell C, van den Hoff J, Wienecke B, Woehler EJ, Wotherspoon S, Hindell MA (2014) Important marine habitat off east Antarctica revealed by two decades of multi-species predator tracking. Ecography 37:1-9

Schröder M, Fahrbach E (1999) On the structure and the transport of the eastern Weddell Gyre. Deep-Sea Res II 46:501-527

Schwegmann S (2012) Interannual and decadal variability of sea ice drift, concentration and thickness in the Weddell Sea $=$ Interannuelle und dekadische Variabilität von Drift, Konzentration und Dicke des Meereises im Weddellmeer. Ber Polar Meeresforsch $=$ Rep Polar Mar Res, Bremerhaven, Alfred Wegener Institute for Polar and Marine Research, 648, $190 \mathrm{pp}$

Siegel V (2005) Distribution and population dynamics of Euphausia superba: summary of recent findings. Polar Biol 29:1-22

Siniff DB, Stirling I, Bengtson JL, Reichle RA (1979) Social and reproductive behavior of crabeater seals (Lobodon carcinophagus) during the austral spring. Can J Zool 57:2243-2255

Siniff DB, Garrott RA, Rotella JJ, Fraser WR, Ainley DG (2008) Projecting the effects of environmental change on Antarctic seals. Antarct Sci 20:425-435

Smetacek V, Scharek R, Nöthig E-M (1990) Seasonal and regional variation in the pelagial and its relationship to the life cycle of krill. In: Kerry KR, Hempel G (eds) Antarctic ecosystems: ecological change and conservation. Springer, Berlin, pp 103-114

Southwell CJ (2004) Satellite-linked dive-recorders provide insights into the reproductive strategies of crabeater seals (Lobodon carcinophagus). J Zool 264:399-402 
Southwell CJ, Kerry KR, Ensor PH (2005) Predicting the distribution of crabeater seals Lobodon carcinophaga off east Antarctica during the breeding season. Mar Ecol Prog Ser 299:297-309

Southwell C, Bengtson JL, Bester M, Blix AS, Bornemann H, Boveng P, Cameron MF, Forcada J, Laake J, Nordøy ES, Plötz J, Rogers T, Southwell D, Steinhage D, Stewart BS, Trathan P (2012) A review of data on abundance, trends in abundance, habitat use and diet of ice-breeding seals in the Southern Ocean. CCAMLR Sci 19:49-74

Taki K, Hayashi T, Naganobu M (2005) Characteristics of seasonal variation in diurnal vertical migration and aggregation of Antarctic krill (Euphausia superba) in the Scotia Sea, using Japanese fishery data. CCAMLR Sci 12:163-172

Teschke K, Dorschel B, Gutt J, Hain S, Hellmer H, Jerosch K, Knust R, Kock K-H, Schlüter M, Siegel V, Brey T (2013) Proposal for the establishment of a marine CCAMLR MPA in the Weddell Sea (Antarctica) - first conceptual outline. Document WGEMM-13/22
Thuiller W, Lafourcade B, Engler R, Araújo MB (2009) BIOMOD—a platform for ensemble forecasting of species distributions. Ecography 32:369-373

Timmermann R, Danilov S, Schröter J, Böning C, Sidorenko D, Rollenhagen K (2009) Ocean circulation and sea ice distribution in a finite element global sea ice-ocean model. Ocean Model 27:114-129

Vincent C, McConnell BJ, Ridoux V, Fedak MA (2002) Assessment of Argos location accuracy from satellite tags deployed on captive gray seals. Mar Mammal Sci 18:156-166

Wall SM, Bradshaw CJA, Southwell CJ, Gales NJ, Hindell MA (2007) Crabeater seal diving behaviour in eastern Antarctica. Mar Ecol Prog Ser 337:265-277

Wisz MS, Hijmans RJ, Li J, Peterson AT, Graham CH, Guisan A, NCEAS Predicting Species Distributions Working Group (2008) Effects of sample size on the performance of species distribution models. Divers Distrib 14:763-773 